\title{
Future Living Arrangement of Older People: A Comparison Between Malaysia and Indonesia
}

\author{
I Komang Astina \\ Faculty of Social Sciences \\ Universitas Negeri Malang, Indonesia \\ Corresponding email: komang.astina.fis@um.ac.id \\ Wan Ibrahim Wan Ahmad \\ School of Applied Psychology, Policy and Social Work \\ Universiti Utara Malaysia
}

\begin{abstract}
As the level of fertility declined and population tends to live longer in all countries, the world is experiencing the growth of older people. Based on the available population data, Malaysia and Indonesia are also experiencing the growth of older people. In fact, these two neighboring countries are on the threshold of an ageing population. One of the major problems facing the older population in Malaysia and Indonesia is a convenient and secure living arrangement in the future. Before this family is a convenient and secure living arrangement to older people. With the high level of urbanization and rural-urban migration in these two countries, has resulted the family is no longer convenient and secure place for older people spend their old age. Therefore this paper aims to analyze the choice of living arrangement of older people in Malaysia and Indonesia. Data for this comparison is depicted from a survey conducted in Yan, Kedah, Malaysia and in Kota Batu, East Java, Indonesia. Results show a significant portion of older people in Yan, Kedah still expecting their spouses as a place of residence in the future. The second largest proportion is living with children. There are also some older people in Malaysia who choose pondok (pesantren) as a place of residence. On the other hand, the majority of older people in Kota Batu, East Java choose to live with children. There are also older people in Kota Batu who choose to live with spouse. Not many older people in Kota Batu who choose to live with other families, and even none of them who is intending to live in pesantren. In conclusion spouse as well as family is still the choice of living arrangement of older people in the future.
\end{abstract}

Keywords-Older people, ageing nations, fertility, living arrangement

\section{INTRODUCTION}

This paper deals with the future of housing choices of elderly population in Indonesia and Malaysia. The choice of residence (living arrangement) of elderly population, in this paper refers to living collectively. The rapid rate of urbanization and industrialization in both countries has led to indecision on the future of the family members, especially children. Children no longer provide a safe place for elderly people to live together. This paper aims to explore the views of the aging population regarding these uncertainties.

Why is the aging population increasing? There are various reasons for this according to the population structure. In general, the increase of elderly population can be explained as a process of demographic transition that occurs in a country's population structure. Demographic transition is a concept that refers to four ranks, namely changing demographics of mortality and high fertility to levels of mortality and low fertility rates (Harries and Norris, 1986). The process of demographic transition occurs due to the socio-economic and technological progress in the field of medicine. The progress made has led to a decrease in the fertility rate as well a decline in the mortality rate of the population. Declining fertility rate makes the proportion of the population in the younger age structure decrease, while the decline in mortality, especially mortality in the elderly, enlarges the structure of the population. Advances in medical technology can cure many diseases thus helping people to live longer. This is happening globally in all countries. The fertility rate has declined and the population tends to live longer globally .It is now that the world is confronted with a new phenomenon, namely aging population.

Currently all countries are experiencing an increase in the number and proportion of elderly population (Ogawa, 1992). Elderly population is the population aged 60 years and over. Increasing aging population is a phenomenon of the 20th century. Before the 20th century not many people survived old age. In 2000 there were 607 million people aged 60 years and over in the world. This further increased to 901 million in 2015. This number has increased by 48 cent in just 15 years and it will 
grow to 1.4 billion in 2030, and increase again to 2.1 billion by 2050 (United Nations, 2015).

Based on the existing population data, Indonesia and Malaysia have experienced an increase in the number of elderly population (Wan Ibrahim Wan Ahmad, Hj Ab Rahman Ashraf, I Komang Astina and Budiyanto, 2013). In fact, the two countries are said to be neighbors on the verge of the old country in line with the increasing number of elderly population that occurs in all other countries. In developed countries, the welfare of elderly population is the responsibility of government (Ogawa, 1992), while in the developing world, including Indonesia and Malaysia, this class welfare is the responsibility of family members.

One of the major problems faced by the elderly in Malaysia and Indonesia is the arrangement of a comfortable and secure residence in the future. Prior to this, family was comfortable and secure for the elderly population. In both countries, children are the main source of donations to this elderly population. In fact, because the child are considered very important to the elderly population,the fertility rate in developing countries is very high. This is to ensure that couples get married, have children who could help them in old age. But with the high level of urbanization and migration from rural to urban areas in these two countries, the family is no longer considered a place that is comfortable and safe for the elderly population in the future. This paper aims to (1) explore the patterns of choice of residence of elderly population in Indonesia and Malaysia, and (2) analyze why people chose such a pattern.

\section{METHOD}

Data for this comparison is derived from the survey conducted in Kota Batu, East Java, Indonesia (I Komang Astina, 2014) and in the area of Yan, Kedah, Malaysia (Wan Ibrahim Wan Ab Rahman and Md Zawawi Khudzri, 2014). The second survey was conducted in 2014. Surveys in Batu were conducted on 322 elderly people, and it aimed to analyze the quality of life stages, while a survey in the area of Yan, Kedah involved 60 elderly people aiming to explore options such as cottages (pesantren) as alternative housing. The second survey consisted of elderly respondents aged 60 years and over. Data for both surveys were carried out through three main approaches, namely questionnaire, interviews, and observations. The Questionnaire consisted of a list of questions prepared in advance.The interviews were conducted informally by asking various problems unthinkable at the time of data collection through questionnaires. From the two surveys,questions relating to about housing options in the future were evident. Information (declaration) in this paper relates to the information obtained from these questions.

\section{FINDINGS AND DISCUSSION}

Questions about the pattern of housing options in the future for the elderly in these two places were aimed to explore the perception of elderly people, whether they regard the family as a safe place for future residence or otherwise. Results of the study found that the pattern of housing choices of elderly population in Indonesia and Malaysia, although different in terms of numbers, showed similar patterns.

\section{A. Pattern of Living Arrangement in Kota Batu}

Most of the elderly in Kota Batu, East Java, Indonesia are still expecting to stay with family. Distribution patterns of selected aging population on the pattern of housing options are shown in Table 1.

TABLE 1: DisTRIBUTION Of LIVING ARRANGEMENT IN KOTA BARU

\begin{tabular}{|l|c|}
\hline \multicolumn{1}{|c|}{ Choice of living patterns } & Kota Batu \\
\hline Living as a couple & 23.9 \\
\hline Living with child and grandchildren & 66.5 \\
\hline Living at Old age homeless shelter & 0.3 \\
\hline With other family members & 2.5 \\
\hline Living alone & 6.8 \\
\hline $\begin{array}{l}\text { Living at Pondok Pesantren (cottage of } \\
\text { Islamic) }\end{array}$ & - \\
\hline
\end{tabular}

Of the 322 elderly residents who responded, $67 \%$ still chose to stay with family members in the future. The number of elderly who believe that they can stay as a couple amounted to $24 \%$ only while $6.8 \%$ want to live alone because do not want to disturb others. The number who believe that they are forced to rely on the nursing home and the family other than children or grandchildren are insignificant. In fact, no respondents wished to stay at the Pondok Pesantren (cottage of Islamic).

\section{B. Pattern of Living Arrangement in Malaysia}

The results largely showed that the elderly population in Yan, Kedah in the period can and wished to live as a couple. Of the total elderly population, nearly half of them feel that living as a couple is safer. The proportion of the latter prefer staying with family (children and grandchildren). There is also a rather large proportion of elderly population in Malaysia who choose the Old age home as a place to stay. The number of elderly population in Yan who chooses to stay at virtues home (nursing) is not much (Table 2). 
TABLE 2: Distribution Of LIVING ARRANGEMENT IN YAN, KEDAH

\begin{tabular}{|l|l|}
\hline Choice of living patterns & Kedah \\
\hline Living as a couple & 43.4 \\
\hline Living with grandchildren & 35.8 \\
\hline Living at Old age homeless shelter & 7.5 \\
\hline Living with other family members & - \\
\hline Living at the cottage (Pondok) & 13.3 \\
\hline
\end{tabular}

In general, there is a difference between the pattern of housing options in the future among the elderly population in Batu and those in Yan, Kedah. In Batu, residents largely feel the family is still a safe place for them to stay in the future, while there is a tendency of elderly population in Yan to feel that the family is no longer a comfortable place to stay at in the future. There is also a rather large elderly population in Yan, Kedah who assume that cottages can be used as a safe alternative housing in the future. But none of the elderly who responded to the survey in Batu, Malang, were eager to stay at the Old age home.

\section{Reasons for their Selection of Housing Options}

Informal interviews have yielded various reasons as to why the elderly choose the pattern stated. Among all other reasons their occupation as a traditional farmer is the major one influencing their stay option. Elderly population in both places agreed traditional farming is the main occupation in both areas of study. A huge proportion of the population engaged in traditional agriculture still lives in the same village with their family members. If in case any family member migrates to the big cities, there will still be other members who would remain in the village. It means that family members can still stay together at the family house available.

The second reason is the reminiscent of the tradition of people who want a traditional marriage, both in Indonesia and in Malaysia. In future, this tradition is expected to remain. Marriage will bring forth children; and the process of family formation will continue both in Indonesia and in Malaysia. Therefore, with the family, the elderly in the family would still be able to rely on their children.

\section{CONCLUSION AND SUGGESTION}

This paper discusses the perception of aging population on the pattern of housing options in the future in Indonesia and Malaysia. The discovery of the study, although different between Indonesia and Malaysia, the respondents in both countries however showed a similar pattern. A proportion of the respondents still feel the group of elderly population in the future could still depend on the family as a place to stay. Although it will be a lot of children who migrate to the cities, they believe there are other children who remain with the family and continue traditional agricultural businesses in the village. They feel and look forward to staying with their own family members.

\section{REFERENCES}

[1] Harries, Keith D. \& Norris, Robert E, (1986), "Human geography: Culture, interaction and economy", Columbus, Merrill Publishing Co.

[2] I Komang Astina, (2014), "Kualiti hidup warga tua di Kota Batu, Jawa Timur", Tesis PhD, Pusat Pengajian Pembangunan Sosial, Universiti Utara Malaysia

[3] Ogawa, N, (1992), Resources for the elderly in economic development, Dlm. Hal L, Kendig et al. (eds.), "Family support for the elderly. The international experience". Oxford: Oxford University.

[4] United Nations, (2015), “World population ageing 2015”, New York, Department of Economic and Social Affairs Population Division.

[5] Wan Ibrahim Wan Ahmad, Asyraf Hj Ab Rahman, I Komang Astina dan Budiyanto, (2013), "Global Distribution of Older Population", Advances in Natural and Applied Scienes 7(4) Special 2013.

[6] Wan Ibrahim, Wan Ab Rahman Khudzri dan Md Zawawi, (2014), "Sikap dan penerimaan warga tua ke atas pondok sebagai tempat tinggal alternatif. Laporan penyelidikan, Pusat Pengajian Pembangunan Sosial, Universiti Utara Malaysia. 